\title{
Gingival health condition among children of inbreeding parents compared to children of outbreeding parents in Babylon governorate / Iraq
}

\author{
Zahraa M Wais ${ }^{(1)}$, Nadia Aftan Al Rawi ${ }^{(2)}$ \\ https://doi.org/10.26477/jbcd.v32i4.2915
}

\begin{abstract} city/ Babylon governorate in Iraq. to index of Loe and Silness (1963). correlation was found between gingival and plaque indices. hygiene and gingival health condition than children of inbreeding parents.

\section{INTRODUCTION}

Inbreeding is defined as a union between two individuals who related as second cousins or other relation. Inbreeding rates differ in communities depending on religion, culture, and geography. ${ }^{(1)}$

As a consequence of inheriting the identical chromosomal segment through both parents, who inherited it from ancestor, the individuals born of consanguineous marriage have a number of pieces of their chromosomes which are homozygous. For this reason, inbreeding increases the homozygosity and, then, recessive alleles masked by heterozygosity with predominant alleles will be assert through inbreeding. Therefore, it is conventional that recessive traits such as most human genetic disorders which occur when frequency increase in the progeny of inbreeding couples. As in more, many recessive alleles found in natural populations that have adverse effects on organism, usually inbreeding make decrease in size, reproductive fitness and vigor. However, it is
\end{abstract}

Background: Consanguineous marriage is a relationship between biologically related individuals. Genetic factors have a role in gene environment interactions that takes the center stage. The evidence of oral disease (gingivitis and periodontitis) may depend on genetic syndromes, inherited diseases, familial studies etc. The present study aims at assessing dental plaque and gingival health condition in children of inbreeding parents compared with children of outbreeding parents among primary schools in Al-Qasem

Materials and methods: this comparative study included three hundred ninety eight (398) students, 6-12 years old, from 4 primary schools; 199 children had their parents of inbreeding marriage with first level of inbreeding, and the other 199 children had parents of outbreeding marriage. Plaque status was assessed according to index of Silness and Loe (1964), gingival health status according

Results: Children of inbreeding parents showed significantly higher plaque index and gingival index mean values than children of outbreeding parents. Mild gingivitis was found as the most prevalent type among both groups. A highly significant positive

Conclusion: Inbreeding rates have an effect on oral health, as the children of outbreeding parents had significantly better oral

Key words: Consanguineous marriage, inbreeding, oral health. (Received: 10/8/2019; Accepted: 1/9/2019)

(1) M.Sc. Student, Department of Pedodontics and Preventive Dentistry, College of Dentistry, University of Baghdad.

(2)Assistant Professor, Department of Pedodontics and Preventive Dentistry, College of Dentistry, University of Baghdad.

Corresponding author, missdentist1990@yahoo.com necessary to consider that consanguineous marriage can happen through two different biological positions. (2)

The degree of relationship between the individuals in a population depends on the size of that population which is more closely related one to other in limited population than in broad one. So, inbreeding is a phenomenon usually combines with small populations. In different circumstances, inbreeding can happen in a large population as a form of nonrandom marriage when the frequency of consanguineous marriage is more than that anticipated by chance. ${ }^{(1,2)}$

Consanguineous marriage is common in many countries, first-cousin marriage and other types of consanguineous marriage are common in a number of general populations from different places of the world. ${ }^{(3,4)}$

Research on the relationship between consanguinity and many parameters of oral and periodontal health status is limited, both in quality and quantity. ${ }^{(5,6)}$ Periodontal disease is genetically inherited and appears to follow an autosomal recessive pattern, even though parents were phenotypically healthy but carried the recessive gene for the syndrome so can appear in their children. An increased prevalence of parental consanguinity around 20$40 \%$ has been reported in Papillon-Lefevre Syndrome patients. ${ }^{(7)}$ Dental plaque can be defined as "the soft non mineralized bacterial deposit which form and adhere firmly to the tooth, clinically can 
be realized when it reaches certain thickness as a whitish or a yellowish layer along gingival margin". (8) Plaque accumulation is greatest in the sheltered interdental region hence gingival inflammation tend to start in the interdental papilla and spreads from there around the neck of the tooth lead to gingivitis. (9)

In a study by Çalışır ${ }^{(10)}$ about relation of inbreeding and oral health between consanguineous and the non-consanguineous groups, the gingival index was higher in the siblings of the consanguineous marriage than non-consanguineous group. In addition, he found displayed the siblings of the consanguineous marriage about eight times more prevalence of aggressive periodontitis than the siblings of the non-consanguineous marriage. Moreover, the mode of transmission of disease was recorded to fit greater to the autosomal recessive inheritance design.

Kindler syndrome, represented as uncommon subtype of inherited epidermolysis bullosa, is characterized by oral symptoms like periodontitis, gingivitis, and loss of teeth. However, a common feature in populations with high rates of inbreeding marriage was Kindler syndrome. (11) Chronic granulomatous disease (CGD) is inherited disease of the innate immune system that is characterized by impaired phagocyte microbicidal activity. It is caused by genetic defects, inherited as an autosomal recessive pattern, and characterized by severe neutropenia. Patients suffer from recurrent gingivitis and even severe periodontitis. To have a family history of consanguineous parenthood may be a predisposing factor for genetic agranulocytosis. (12)

In 1995, dental examination of 120 pupils aged (619) years old with high prevalence of inbreeding $69 \%$ were studied and compared to Tunisian pediatric dentistry society (TPDS) that outbreeding marriage. The results showed similar caries experience, and that carious process is infectious and not inherited. ${ }^{(13)}$

This study was conducted in order to assess the impact of inbreeding on oral hygiene and gingival health condition in comparison to children of outbreeding parents.

\section{MATERIALS AND METHODS}

Three hundred ninety eight (398) students, 6-12 years old, were collected from 4 primary schools, they were divided into 199 children that their parents of first level of inbreeding marriage (study group), and other 199 children their parents outbreeding marriage (control group), in Al-Qasem city/ Babylon governorate, in Iraq. This comparative study sample was calculated by the formula: $\mathrm{n}=\mathrm{ZP} 2(1-\mathrm{P}) / \mathrm{d} 2$. $^{(14)}$

This study was done during the period from December 2018 to February 2019. A pre-study ethical approval was assigned, also the children's parent consent form was taken before starting the study. Family history of type of marriage was taken. Information on the type of marriage of the parents was obtained; whether the inbreeding marriage or outbreeding marriages by answering the papers presented to them as seen in descriptive statistics of consanguineous marriage for both the Pakistan and the Bangladesh. ${ }^{(15)}$

Inclusion criteria; students with:

- No history of medication, (antimicrobial treatment or anti- inflammatory) within last three months.

-No history of orthodontic treatment. Diagnostic criteria included the gender, age and history of family if inbreeding parents or not.

Oral examination was performed on chairs, under good illumination by using dental mirror, probe and dental tweezers following the main approach of the oral health survey recommended by (WHO, 1997). Oral cleanliness was assessed according to the criteria of plaque index by Silness and Loe (1964) ${ }^{(16)}$ by examining the thickness of plaque at the cervical margin of the tooth. Four areas were examined, distal, facial or buccal, mesial, and lingual. The 6 index teeth were examined to represent entire dentition.

Gingival condition was assessed using Loe and Silness (1963) ${ }^{(17)}$, the GI assesses the severity of gingivitis based on consistency, color and bleeding on probing. It describes the severity of gingival inflammation and its location. Mesial, lingual, distal, and facial (or buccal) surface of teeth were examined .

Data description, analysis and presentation were performed using the statistical package for social sciences (SPSS, version 21). Statistical analysis included:

1-Descriptive analysis: mean and SE.

2-Inferential analysis: $T$ test, Spearman correlation (r), (p-value $<0.05$ considered significant).

\section{RESULTS}

Table 1 demonstrates the distribution of total sample by age. A high percentage of students was found at age group 6-10 years old among both groups. The distribution of total sample according to gender is seen in table 2. This table shows a 
higher percentage of females was recorded among both groups .

Table (1): Distribution of the total sample by age among inbreeding and outbreeding.

\begin{tabular}{||c|c|c|c||}
\hline \multirow{2}{*}{ Groups } & \multicolumn{2}{c|}{ Age (years) } \\
\cline { 3 - 4 } \multicolumn{2}{|c|}{} & $6-10$ & $+10-12$ \\
\hline \multirow{2}{*}{ Inbreeding } & $\mathrm{N}$ & 130 & 69 \\
\cline { 2 - 4 } & $\%$ & 65.3 & 34.6 \\
\hline \multirow{2}{*}{ outbreeding } & $\mathrm{N}$ & 140 & 59 \\
\cline { 2 - 4 } & $\%$ & 70.3 & 29.6 \\
\hline
\end{tabular}

Table (2): Distribution of total sample by gender among inbreeding and outbreeding.

\begin{tabular}{||c|c|c|c||}
\hline \multicolumn{2}{|c|}{ Groups } & \multicolumn{2}{c|}{ Gender } \\
\cline { 2 - 4 } & Male & Female \\
\hline \multirow{2}{*}{ Inbreeding } & $\mathrm{N}$ & 98 & 101 \\
\cline { 2 - 4 } & $\%$ & 49.25 & 50.75 \\
\hline \multirow{2}{*}{ outbreeding } & $\mathrm{N}$ & 96 & 103 \\
\cline { 2 - 4 } & $\%$ & 48.24 & 51.76 \\
\hline
\end{tabular}

Table 3 demonstrates the mean value and SE of plaque index according to age, gender and breeding rate among children. Regarding age group, the result showed a higher mean value of plaque index at age 6-10 years old than children at age 10.1-12 years among in breeding group, while for outbreeding group, the result was opposite showed the children at age 10.1-12 years had higher plaque index mean than children at age 6-10 years. For the total sample this table shows that the mean value of dental plaque index was $2.05 \pm 0.05$ in inbreeding group and 1.16 \pm 0.06 among outbreeding group, statically highly significant differences were existed between two groups with $\mathrm{P}=0.00$.

Table (3): Mean and standard error of plaque among inbreeding and outbreeding by age and gender.

\begin{tabular}{|c|c|c|c|c|c|}
\hline \multirow{3}{*}{$\begin{array}{c}\text { Age } \\
(\mathbf{Y})\end{array}$} & \multicolumn{4}{|c|}{ Groups } & \multirow{3}{*}{$\mathbf{T}$} \\
\hline & \multicolumn{2}{|c|}{ Inbreeding } & \multicolumn{2}{|c|}{ outbreeding } & \\
\hline & $\mathbf{N}$ & $\begin{array}{l}\text { Mea } \\
\text { n }\end{array}$ & $\mathbf{N}$ & Mean & \\
\hline \multirow{3}{*}{$\begin{array}{l}<= \\
10\end{array}$} & 63 & 2.06 & 61 & 1.02 & 7.07 \\
\hline & 67 & 2.16 & 79 & 1.20 & 7.23 \\
\hline & 130 & 2.12 & 140 & 1.12 & $\mathbf{1 0 . 0}$ \\
\hline \multirow{3}{*}{$\begin{array}{l}10 \\
+\end{array}$} & 35 & 1.86 & 35 & 1.31 & 2.76 \\
\hline & 34 & 1.97 & 24 & 1.19 & 3.45 \\
\hline & 69 & 1.91 & 59 & 1.26 & 4.42 \\
\hline Total & 199 & 2.05 & 199 & 1.16 & 10.6 \\
\hline \multicolumn{6}{|c|}{ p value $0.00 *$ significant $p<0.05$} \\
\hline
\end{tabular}

Mean value of gingival index tended to be higher in inbreeding group than in outbreeding group, differences were statistically highly significant existed between both groups $(\mathrm{p}=0.00)$. In addition, gingival index tended to be higher in age group (610) compared with age group (10.1-12) among both inbreeding and outbreeding groups (table 4).

Table (4): Mean and standard error of gingival index among inbreeding and outbreeding by age and gender.

\begin{tabular}{|c|c|c|c|c|c|c|c|}
\hline \multirow{3}{*}{$\begin{array}{l}\text { Age } \\
\text { (Y) }\end{array}$} & \multirow{3}{*}{ G } & \multicolumn{4}{|c|}{ Groups } & \multirow{3}{*}{$\mathbf{T}$} & \multirow{3}{*}{$\underset{\text { value }}{\mathbf{p}}$} \\
\hline & & \multicolumn{2}{|c|}{ Inbreeding } & \multicolumn{2}{|c|}{ outbreeding } & & \\
\hline & & $\mathbf{N}$ & Mean & $\mathbf{N}$ & Mean & & \\
\hline \multirow{3}{*}{$<=10$} & $\mathbf{M}$ & 63 & 2.06 & 61 & 1.02 & $7.07 *$ & .00 \\
\hline & $\mathbf{F}$ & 67 & 2.16 & 79 & 1.20 & 7.23* & .00 \\
\hline & $T$ & 130 & 2.12 & 140 & 1.12 & $10.0^{*}$ & .00 \\
\hline \multirow{3}{*}{$10+$} & $\mathbf{M}$ & 35 & 1.86 & 35 & 1.31 & $2.76^{*}$ & .00 \\
\hline & $\mathbf{F}$ & 34 & \begin{tabular}{|l|}
1.97 \\
\end{tabular} & 24 & 1.19 & $3.45^{*}$ & .00 \\
\hline & $\mathbf{T}$ & 69 & 1.91 & 59 & 1.26 & $4.42 *$ & .00 \\
\hline \multicolumn{2}{|c|}{ Total } & 199 & 2.05 & 199 & 1.16 & $10.6^{*}$ & .00 \\
\hline \multicolumn{8}{|c|}{$*$ significant $\mathrm{p}<0.05$} \\
\hline
\end{tabular}

A highly significant strong positive correlation coefficient was recorded between plaque and gingival index among inbreeding group, while highly significant weak positive was found in outbreeding group (table 5).

Results showed mild gingivitis was the most common type of gingival severity among children, followed by a moderate and severe type (table 6).

Table (5): Correlation coefficient between plaque index and gingival index among inbreeding and outbreeding.

\begin{tabular}{||c|c|c|c||}
\hline \multicolumn{2}{|l|}{ Groups } & $\begin{array}{c}\text { Gingival } \\
\text { index }\end{array}$ \\
\hline Inbreeding & $\begin{array}{c}\text { Plaque } \\
\text { index }\end{array}$ & $\mathrm{r}$ & $.542^{*}$ \\
\cline { 3 - 5 } outbreeding & \multirow{2}{*}{$\begin{array}{c}\text { Plaque } \\
\text { index }\end{array}$} & $\mathrm{p}$ & .000 \\
\cline { 3 - 5 } & & $\mathrm{p}$ & .000 \\
\hline
\end{tabular}


Table (6): Distribution of children according to gingival health condition among inbreeding and outbreeding.

\begin{tabular}{|c|c|c|c|c|c|}
\hline \multirow{3}{*}{$\begin{array}{l}\text { Age } \\
\text { (Y) }\end{array}$} & \multirow{3}{*}{ Groups } & \multicolumn{4}{|c|}{ GI severity } \\
\hline & & \multirow{2}{*}{$\begin{array}{c}\begin{array}{c}0.1-1 \\
\text { Mild }\end{array} \\
\%\end{array}$} & \multirow{2}{*}{$\begin{array}{c}\begin{array}{c}1.1-2 \\
\text { Moderate }\end{array} \\
\%\end{array}$} & \multicolumn{2}{|c|}{ 2.1-Severe } \\
\hline & & & & No. & $\%$ \\
\hline \multirow{3}{*}{ 6-10 } & $\begin{array}{c}\text { Inbree } \\
\text { ding }\end{array}$ & 42.3 & 39.23 & 15 & 11.5 \\
\hline & $\begin{array}{l}\text { Outbree- } \\
\text { ding }\end{array}$ & 25.0 & 17.14 & 0 & .00 \\
\hline & Total & 33.3 & 27.78 & 15 & 5.56 \\
\hline \multirow{3}{*}{$10+$} & $\begin{array}{c}\text { Inbree- } \\
\text { ding }\end{array}$ & 34.7 & 33.33 & 10 & 14.4 \\
\hline & $\begin{array}{c}\begin{array}{c}\text { Outbree- } \\
\text { ding }\end{array} \\
\end{array}$ & 38.9 & 8.47 & 0 & .00 \\
\hline & Total & 36.7 & 21.88 & 10 & 7.81 \\
\hline \multirow{3}{*}{ Total } & $\begin{array}{c}\text { Inbree- } \\
\text { ding }\end{array}$ & 39.7 & 37.19 & 25 & 12.5 \\
\hline & $\begin{array}{c}\text { Outbree- } \\
\text { ding }\end{array}$ & 29.1 & 14.57 & 0 & .00 \\
\hline & Total & 34.4 & 25.8 & 25 & 6.2 \\
\hline
\end{tabular}

\section{DISCUSSION}

To our knowledge, there was no previous Iraqi study to compare the findings of this study with. Therefore, the data of current study can be compared with other studies in other countries in the world regarding impact of inbreeding on oral health of their children.

Dental plaque thickness and gingival health status were assessed in the present study among children of inbreeding parents and children of outbreeding parents using plaque index of Silness and Loe ${ }^{(16)}$ and gingival index of Loe and Silness. ${ }^{(17)}$ These indices are widely used in the controlled and epidemiological studies because of their flexibility which provides the possibility of measuring the severity of the disease and to get more precise result to overcome any inaccuracy due to missing teeth. Another advantage is the ease of application. ${ }^{(18)}$

In this study, the plaque index showed highly significant differences between children of inbreeding marriage and children of outbreeding marriage. This may be related to genetic factors, ${ }^{(19)}$ lifestyle and work, and environment. ${ }^{(20)}$ In addition, the evidence of periodontitis is dependent on the genetic syndromes, inherited diseases, familial studies etc. ${ }^{(21)}$ Susceptibility of periodontal diseases is inherited as an X-linked dominant trait. Evidence of plaque index has been confirmed by studies of fraternal twins and identical twins which reared together and identical twins reared apart. ${ }^{(22)}$

Results of current study revealed that gingival index showed highly significant differences between children of inbreeding marriage and children of outbreeding marriage, which could be due to that periodontal disease is genetically inherited and appears to follow an autosomal recessive pattern, even though parents were phenotypically healthy but carried the recessive gene for the syndrome, so can appear in their children. ${ }^{(7)}$

As mean of plaque index, mean of gingival index increase, this due to positive highly significant correlation between plaque and gingival indices in this study, and this in agreement with study done by Layth and Al-Rawi who reported positive highly significant relation between gingival index and plaque index. ${ }^{(23)}$ This may be attributed to that when dental plaque increases, bacteria increase in number and increase in bacterial toxins which lead to increase in gingival disease ${ }^{(24)}$

\section{CONCLUSION}

The gingival disease was significantly higher in inbreeding group than in outbreeding group, with a worst oral hygiene.

\section{REFERENCES}

1. Bittles AH. Consanguinity and its relevance to clinical genetics. Clinical genetics. 2001 Aug;60(2):89-98.

2. Alvarez G, Quinteiro C, Ceballos FC. Inbreeding and genetic disorder. In Advances in the study of genetic disorders 2011 Nov 21.

3. Lauc T, Rudan P, Rudan I, Campbell H. Effect of inbreeding and endogamy on occlusal traits in human isolates. Journal of orthodontics. 2003 Dec $1 ; 30(4): 301-8$

4. Bener A, Hussain R. Consanguineous unions and child health in the State of Qatar. Paediatric and Perinatal Epidemiology. 2006;20: 372-378

5. Bittles AH, Black ML. Consanguinity, human evolution, and complex diseases. Proceedings of the National Academy of Sciences. 2010 Jan 26; 107 (suppl 1):1779-86.

6. Tadmouri GO, Nair P, Obeid T, Al Ali MT, Al Khaja $\mathrm{N}$, Hamamy HA. Consanguinity and reproductive health among Arabs. Reproductive health. 2009; 6 (1): 17 .

7. Ragupathy, K., Prlyadharsini, I. and Pasupathy, S. Parental Consanguinity as Risk Factor in PapillonLefevre Syndrome: AC ase Report. Int J Dent Med Res. 2015 1(6), p.68.

8. Dumitrescu AL, Kawamura M. Etiology of periodontal disease: dental plaque and calculus. In Etiology and pathogenesis of periodontal disease 2010 Jan 1 (pp. 138). Springer Berlin Heidelberg.

9. Marya CM. A textbook of public health dentistry. JP Medical Ltd; 2011 Mar 14.

10. Çalışır $M$. Consanguinity increases the risk for aggressive periodontitis. J Period Res. 2018 Oct; 53 (5):902-9.

11. Youssefian L, Vahidnezhad $\mathrm{H}$, Saeidian AH, Ahmadizadeh K, Has C, Uitto J. Kindler syndrome, an 
orphan disease of cell/matrix adhesion in the skinmolecular genetics and therapeutic opportunities. Expert Opinion on Orphan Drugs. 2016 Aug 2;4(8):845-54.

12. Zeidler C, Germeshausen M, Klein C, Welte K. Clinical implications of ELA2-, HAX1-, and G-CSF-receptor (CSF3R) mutations in severe congenital neutropenia. BJ of haematology. 2009 Feb;144(4):459-67.

13. Maatouk f, laamiri d, argoubi k, ghedira h. Dental manifestations of inbreeding. $\mathrm{J}$ clin pediatr dent. 1995;19(4),pp.305-6.

14. Daniel WW. Biostatistics: A Foundation for Analysis in the Health Science. 7th edn. New York: John Wiley and sons. 1999.

15. Mobarak AM, Chaudhry T, Brown J, Zelenska T, Khan MN, Chaudry S, Wajid RA, Bittles AH, Li S. Estimating the health and socioeconomic effects of cousin marriage in South Asia. J of biosocial science. 2019 May;51(3):418-35

16. Silness J, Löe H. Periodontal disease in pregnancy II. Correlation between oral hygiene and periodontal condition. Actaodontologicascandinavica. 1964 Jan 1;22 (1):121-35.

17. Löe H, Silness J. Periodontal disease in pregnancy I. Prevalence and severity. Actaodontologica scandinavica. 1963 Jan 1; 21 (6):533-51.
18. Senevirate CJ, Zhang CF, Samaranayake LP. Dental plaque biofilm in oral health and disease. Chin. $\mathrm{J}$ of Dent. Research. 2011 Jan 1; 14 (2):87

19. Murray J, Nunn J, Steel J. (2003): The prevention of oral disease. 4th ed.96-121. Oxford, New York.

20. Petersen PE, Bourgeois D, Ogawa H, Estupinan-Day S, Ndiaye $\mathrm{C}$. The global burden of oral diseases and risks to oral health. Bulletin of the World Health Organization. 2005; 83: 661-9.

21. Taba Jr M, Souza SL, Mariguela VC. Periodontal disease: a genetic perspective. Brazilian oral research. 2012; 26 (SPE1):32-8.

22. Tarannum F, Faizuddin $M$. Effect of gene polymorphisms on periodontal diseases. Indian J. Hum. Genet. 2012 Jan; 18 (1):9.

23. Layth NM. Al-Rawi NA. Oral health status in relation to nutritional status among a group of 13-15 years old intermediate school girls in Al-Najaf City/Iraq Master thesis, College of Dentistry, University of Baghda,( 2017.

24. Lang NP, Lindhe J, editors. Clinical periodontology and implant dentistry, 2 Volume Set. John Wiley \& Sons; 2015 Mar 25.

الخلفية: زو اج الأقارب هو علاقة بين الأفر اد ذوي الصلة بيولوجيا. العوامل الور اثية لها دور في التفاعلات البيئة الجينية تأخذ مركز الصدارة. يعتمد الدليل على أمر اض الفم (التهاب اللثة والتهاب اللثة و العظم) على در اسة الأمر اض الور اثثية و المتلازمات الور اثثية و الدر اسات العائلية وما إلى ذللك الفمد

اهداف الدر اسة: أجريت هذه الدر اسة لتقييم حدوث وانتاء أنتار نظافة الفم (الحالة الصحية للثة اللويحة السنية) عند الأطفال من أولياءمتزوجين

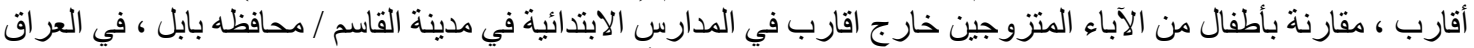

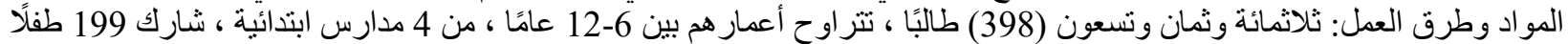

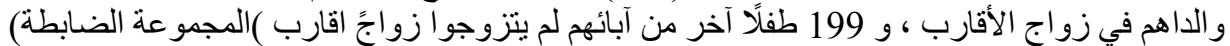

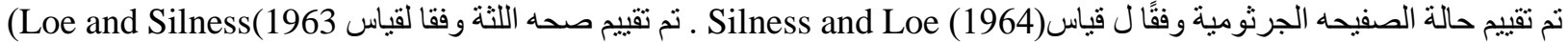

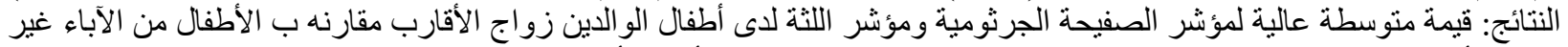

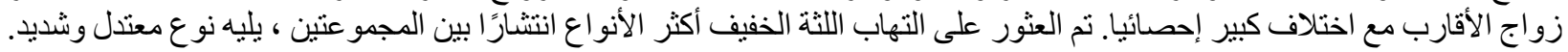

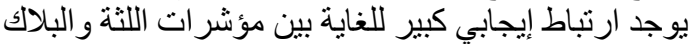

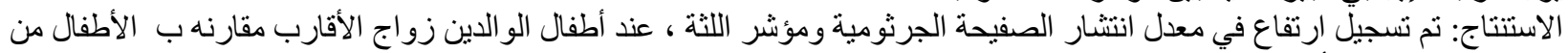
الآباء زواج خارج الأنقارب. 